\title{
Beef cattle production in established integrated systems
}

\section{Produção de bovinos de corte em sistemas de integração estabelecidos}

\author{
Érick Lemes Gamarra ${ }^{1 *}$; Maria da Graça Morais²; Roberto Giolo de Almeida ${ }^{3}$; \\ Natália Aguiar Paludetto ${ }^{4}$; Mariana Pereira ${ }^{5}$; Caroline Carvalho de Oliveira ${ }^{6}$
}

\begin{abstract}
The aim of the current study is to assess three integrated systems presenting different eucalyptus tree densities due to animal and forage production. The following integrated systems were assessed: croplivestock-forest with 357 eucalyptus trees $\mathrm{ha}^{-1}$ (ICLF1); crop-livestock-forest with 227 eucalyptus trees ha ${ }^{-1}$ (ICLF2); and crop-livestock with 5 remnant native trees ha ${ }^{-1}$ (ICL). The randomized block experimental design was applied in a split-plot scheme with four replicates. The Average Daily Gain (ADG, $\mathrm{g}_{\text {animal }}{ }^{-1} \mathrm{day}^{-1}$ ) and the live-weight gain per area (LWG, $\mathrm{kg} \mathrm{ha}^{-1}$ ) were applied to analyze animal performance, which was set by weighing the animals every 28 days (the animals previously fasted for 16h). Forage yield was higher in ICL during fall and winter; in summer, it did not differ from ICLF2. There was no forage yield difference between the ICL and ICLF2 systems in any of the assessed seasons; summer was more productive in ILPF1 than other seasons. The highest leaf crude protein contents (CP) in summer was recorded in systems ICLF1 and ICLF2, and the highest value recorded in fall was found in ILPF1; the lowest was found in ILP. On the other hand, the highest leaf NDF contents in summer were found in ILP. The highest ADG were found in summer. The highest LWG values recorded for the ICL and ICLF2 systems were collected in summer and fall; there was no difference in any of the three systems in winter. The LWG was higher in all system in summer. The ICLF2 emerged as the system (with trees) most appropriate for beef cattle production. Despite the shading interference on forage production, such condition is compensated by the best nutritional contents such as $\mathrm{CP}$. The ICLF2 system allowing an annual LWG of $83 \%$ in relation to the ICL system during the fifth year of establishment of the systems.
\end{abstract}

Key words: Piatã grass. Tree density. Eucalyptus. Crop-livestock-forest integration. Forage yield.

\section{Resumo}

Objetivou-se avaliar três sistemas de integração com diferentes densidades de árvores de eucalipto quanto à produção forrageira e animal. Foram avaliados os sistemas de integração: lavoura-pecuáriafloresta, com 357 árvores de eucalipto ha ${ }^{-1}$ (ILPF1); lavoura-pecuária-floresta, com 227 árvores de eucalipto ha-1 ${ }^{-1}$ (ILPF2) e lavoura-pecuária, com cinco árvores nativas remanescentes ha ${ }^{-1}$ (ILP). Na

1 Zootecnista, M.e em Ciência Animal, Universidade Federal de Mato Grosso do Sul, UFMS, Faculdade de Medicina Veterinária e Zootecnia, FAMEZ, Campo Grande, MS, Brasil. E-mail: erickgamarra2@hotmail.com

2 Prof., UFMS, FAMEZ, Programa de Pós-Graduação em Ciência Animal, Campo Grande, MS, Brasil. E-mail: morais. mariazinha@gmail.com

3 Pesquisador, Empresa Brasileira de Pesquisa Agropecuária, EMBRAPA Gado de Corte, Campo Grande, MS, Brasil. E-mail: roberto.giolo@embrapa.br

4 Analista Instrumental, Bióloga, Secretaria Municipal de Meio Ambiente, SEMMA, Rondonópolis, MT, Brasil. E-mail: nataliaapaludetto@gmail.com

5 M.e em Ciência Animal, UFMS, FAMEZ, Campo Grande, MS, Brasil. E-mail: maripereirazoo@gmail.com

6 Discente de Doutorado em Ciência Animal, UFMS, FAMEZ, Campo Grande, MS, Brasil. E-mail: oliveirac.caroline@gmail.com

* Author for correspondence 
avaliação da forrageira foi adotado o delineamento experimental em blocos casualizados, em esquema de parcelas (ILPF1, ILPF2 e ILP) subdivididas (verão, outono e inverno), com quatro repetições. Para avaliação do desempenho animal, foi utilizado o ganho médio diário (GMD) e ganho de peso vivo por área (GPV), obtidos por pesagens a cada 28 dias com jejum prévio de 16 horas. A produção forrageira foi maior no ILP nas três estações mas, no verão, não diferiu do ILPF2. De maneira geral, os maiores teores de proteína bruta foram encontrados no sistema ILPF1 e os maiores teores de FDN, no sistema ILP. Os maiores GMD ( $\mathrm{g}$ animal $\left.{ }^{-1} \mathrm{dia}^{-1}\right)$ foram no verão. Foram observados maiores GPV $\left(\mathrm{kg} \mathrm{ha}^{-1}\right)$ no verão e outono nos sistemas de ILP e ILPF2, no inverno não houve diferença entre os sistemas. O GPV no verão foi superior em todos os sistemas. O sistema de ILPF2 mostrou ser o sistema com árvores mais propício à produção animal apesar de o sombreamento interferir na produtividade forrageira, permitindo um GPV anual de $83 \%$ em relação ao sistema ILP, durante o quinto ano do estabelecimento dos sistemas.

Palavras-chave: Capim-piatã. Densidade de árvores. Eucalipto. Integração lavoura-pecuária-floresta. Produção de forragem.

\section{Introduction}

Integrated crop-livestock (ICL) and croplivestock-forest (ICLF) systems lead to better land and soil use, to higher yield per cultivated area, besides diminishing the need of opening new sites for agricultural and livestock expansion. These systems use rotation activities within the same area, fact that enables generating new income to farmers through the trading of products resulting from agriculture (grains), livestock (beef) and forestry (timber).

The ICLF systems provide grain, forage and tree production techniques based on rotation or consortium; moreover, they promote a shady microclimatic environment, which is pleasant both for the animals - mainly for European bovine breeds, which are not adapted to the heat - and for plants growing under tree canopies. It happens because the shades can increase soil humidity, help recovering the organic matter contents - which are essential to assure culture yield in succession system -, and reduce weed and nematode amounts (BALBINO et al., 2011; BUNGENSTAB; ALMEIDA, 2014).

Despite its general advantages, forage production in these systems is affected by tree shades, because lower light incidence reduces photosynthesis and carbon fixation in plants, fact that diminishes dry matter yield (SOUSA et al., 2007; LEONEL et al., 2009). Thus, the successful cattle production in ICLF systems depends on the choice for forage grass species tolerant to shading and able to reach maximum dry matter yield, such as Brachiaria brizantha cvs. Marandu, Xaraés and Piatã, Brachiaria decumbens cv. Basilisk, among others (MARTUSCELLO et al., 2009; VARELLA et al., 2009).

Piatã grass stands out among Brachiaria brizantha cultivars due to its easy establishment process, good yield in moderate fertility soils, high accumulation rates and good growth even when they are subjected to grazing. Moreover, Piatã grass leads to good animal performance in consortium with annual cultures, besides its good forage yield, mainly during drought periods (VALLE et al., 2011).

Although there is forage dry matter yield reduction in many ICLF systems, animal performance can be favored by it, since plants kept under tree canopies present better nutritional value. Such nutritional status result from the higher nutrient input from organic matter decomposition and nutrient recycling, mainly of nitrogen, which is used in leaf protein synthesis. It is worth highlighting that leaf protein synthesis increases the forage crude protein content (PACIULLO et al., 2007; LEONEL et al., 2009; KIRCHNER et al., 2010).

Thus, the aim of the current study was to assess three integrated systems with different eucalyptus tree densities in face of forage and cattle production. 


\section{Materials and Methods}

The experiment was performed at Embrapa Gado de Corte, Campo Grande, Mato Grosso do Sul State $\left(20^{\circ} 27^{\prime} \mathrm{S}, 54^{\circ} 37^{\prime} \mathrm{W}\right.$, altitude $\left.530 \mathrm{~m}\right)$, between December 2013 and August 2014. Three integrated systems in soy succession were assessed within an 16ha site, which was divided into 12 plots measuring approximately 1.3 ha each: crop-livestock-forest with 357 eucalyptus trees ha-1 (ICLF1); croplivestock-forest with 227 eucalyptus trees $\mathrm{ha}^{-1}$ (ICLF2); and crop-livestock with 5 remnant native trees $\mathrm{ha}^{-1}$ ( ICL, control).

The soil in the experimental site is classified as dystrophic red latosol with clayey texture. The chemical analysis applied to the soil samples, which were collected from 0 to $20 \mathrm{~cm}$ deep the soil, showed that the site was relatively uniform and presented clay content $41 \pm 5 \%$; $\mathrm{P}$ (Mehlich-1) from 0.29 to $0.42 \mathrm{mg} \mathrm{dm}^{-3}$ base saturation from $26 \%$ to $34 \%$; and aluminum saturation from $10 \%$ to $23 \%$. The climate in the region, according to the Köeppen classification, is in the transition between Cfa and Aw tropical humid; mean rainfall is $1,560 \mathrm{~mm}$, and the water period lasts from November to March $70 \%$ to $80 \%$ of annual rainfall.

Limestone and gypsum (3.0 and $1.0 \mathrm{t} \mathrm{ha}^{-1}$, respectively) were placed before the integrated systems were implemented, between August and September 2008. The eucalyptus seedlings (Eucalyptus urophylla $x$ E. grandis - clone H13) were transplanted to the experimental site in order to form the ICLF1 and ICLF2 systems. The seedlings were distributed in simple rows in both systems; however, under different arboreal density, 357 trees $\mathrm{ha}^{-1}$ and 227 trees $\mathrm{ha}^{-1}$, respectively. The distances between tree lines were $14 \mathrm{~m}$ and $22 \mathrm{~m}$, respectively. Distance between trees within each row was kept in $2 \mathrm{~m}$. Grazing was forbidden until the trees reached diameter at breast height (DBH) higher than $60 \mathrm{~mm}$, in order to avoid damages caused by the animals. Soy was the first cycle crop (2008) and Piatã grass was the first implanted forage, which had its yield preserved as hay (2009) and used under grazing (2009-2012).

The second assessment cycle in the systems sites started in November 2012 with the soy plantation through transgenic early cycle cultivar, BRS $318 \mathrm{RR}$. Liming was performed by using $2 \mathrm{t} \mathrm{ha}^{-1}$ of dolomitic limestone and fertilization (NPK 0-20-20) at the basis $300 \mathrm{~kg} \mathrm{ha}^{-1}$ (QUINTINO et al., 2013).

Soy was harvested in April 2013; subsequently, the mechanic Piatã grass sowing was conducted along with the fertilizer at seeding rate 60 viable pure seeds $\mathrm{m}^{-2}$ and $0.25 \mathrm{~m}$ spacing (MECABÔ, 2014).

The chemical analysis applied to the 2011 soil samples, collected from 0 to $20 \mathrm{~cm}$ deep the ground, presented $\mathrm{P}$ content (Mehlich-1) $3.2 \mathrm{mg} \mathrm{dm}^{-3}$; $\mathrm{K}, 54.74 \mathrm{mg} \mathrm{dm}{ }^{-3}$; Ca, $2.08 \mathrm{cmol}_{\mathrm{c}} \mathrm{dm}^{-3} ; \mathrm{Mg}, 1.28$ cmol $\mathrm{dm}^{-3}$; organic matter, $36.7 \mathrm{~g} \mathrm{~kg}^{-1}$, and base saturation, $50 \%$.

The meteorological data from the integrated systems' surroundings were daily collected in the meteorological station (A702 - INMET), which is located approximately $3 \mathrm{~km}$ away from the experimental site (Table 1).

During the experimental period, the trees of the ICLF systems were from 25 to $27 \mathrm{~m}$ height.

Forage assessments were carried out before the animals were weighed, 10 forage samples were randomly collected within each plot, in each system. A frame of sample area $1.0 \times 1.0 \mathrm{~m}$ was used for forage cut. Canopy height was measured before the forage was cut by using a graduate ruler. The visual assessment of soil cover and forage cut at ground level was performed by using an electric scythe. Sites occupied by trees were excluded from the dry matter yield calculation $\left(\mathrm{ICLF} 1=964 \mathrm{~m}^{2} \mathrm{ha}^{-1}\right.$ and ICLF2 $=614 \mathrm{~m}^{2} \mathrm{ha}^{-1}$ ).

Subsequently, the cut material was weighed and divided in sub-samples, which were separated into leaf blade, sheathed stem and senescent material fractions. Next, they were placed in force air- 
circulation oven at $55^{\circ} \mathrm{C}$ until reaching constant mass for total dry mass and Piatã grass leaf dry mass yield assessment. The Piatã grass leaf blades were ground in 1-mm mesh sieve in order to find the crude protein contents $(\mathrm{CP}, \%)$ and the neutral detergent fiber contents (NDF, \%). It was performed by using the near-infrared spectroscopy (NIRS), according to Marten et al. (1985).

Table 1. Mean temperature (mean T) and rainfall values in 2013 and 2014.

\begin{tabular}{|c|c|c|c|c|c|}
\hline \multirow[b]{2}{*}{ Month } & \multicolumn{2}{|c|}{2013} & \multirow[b]{2}{*}{ Month } & \multicolumn{2}{|c|}{2014} \\
\hline & $\begin{array}{c}\text { Mean T } \\
\left({ }^{\circ} \mathrm{C}\right)\end{array}$ & $\begin{array}{c}\text { Rainfall } \\
(\mathrm{mm})\end{array}$ & & $\begin{array}{c}\text { Mean T } \\
\left({ }^{\circ} \mathrm{C}\right)\end{array}$ & $\begin{array}{c}\text { Rainfall } \\
(\mathrm{mm})\end{array}$ \\
\hline January & 25.5 & 218.3 & January & 24.6 & 162.3 \\
\hline February & 24.7 & 215.8 & February & 25.1 & 111.8 \\
\hline March & 24.9 & 187.2 & March & 24.3 & 163.3 \\
\hline April & 22.5 & 210.8 & April & 24.1 & 52.6 \\
\hline May & 22.2 & 14.9 & May & 20.6 & 165.5 \\
\hline June & 21.0 & 36.5 & June & 20.7 & 51.1 \\
\hline July & 19.7 & 0.0 & July & 20.1 & 115.2 \\
\hline August & 20.2 & 0.0 & August & 23.0 & 17.7 \\
\hline September & 23.4 & 105.5 & September & 25.5 & 66.0 \\
\hline October & 24.5 & 122.2 & October & 27.0 & 19.7 \\
\hline November & 25.2 & 249.6 & November & 24.7 & 217.8 \\
\hline December & 25.5 & 170.8 & December & 24.9 & 359.4 \\
\hline
\end{tabular}

The grazing method adopted to assess animal performance in the three integrated systems was the continuous grazing with varying stocking rate applied from December 2013 to August 2014. All assessed animals were vaccinated and de-wormed at the beginning of the experiment; they were also treated with water and mineral supplementation ad libitum throughout the assessment period.

Two test-animals (females) belonging to the Nellore breed presenting average live weight $180 \mathrm{~kg}$ were used in each plot to measure the appropriate grazing management; regulator animals (put and take) were used whenever necessary. Pasture height was kept in approximately $35 \mathrm{~cm}$. The average daily gain (ADG) and the live weight gain per area (LWG) were adopted to assess animal performance; the values were collected through weightings conducted every 28 days (animals were subjected to previous 16-h fasting), adapted from Oliveira et al. (2013).

The randomized block experimental design was applied in a split-plot scheme with four replicates. Plot treatments corresponded to the following integrated systems: ICLF1, ICLF2 and ICL. Subplot treatments corresponded to the season of the year: summer, fall and winter. Months representing summer were December, January and February; fall was represented by March, April and May; and winter was represented by June, July and August.

Data were subjected to analysis of variance and the means were grouped through the Scott-Knott test at $5 \%$ probability level, in the SISVAR statistical app, version 5.3 (FERREIRA, 2011). 


\section{Results and Discussion}

Significant differences in Piatã grass total dry matter yield were observed $\left(\mathrm{kg} \mathrm{ha}^{-1}\right)$ in the integrated systems (Table 2). Summer season production was higher in the ICL system than in ICLF1, which did not differ from ICLF2. There was also higher fall and winter production in ICL than in the other two systems with trees, which did not differ from each other.

Table 2. Mean of Piatã grass dry mass yield $\left(\mathrm{kg} \mathrm{ha}^{-1}\right)$, in the integrated systems: crop-livestock (ICL), crop-livestockforest with 357 trees ha-1 $^{-1}$ (ICLF1); and crop-livestock-forest with 227 trees ha-1 (ICLF2), in three seasons of the year.

\begin{tabular}{cccc}
\hline \multirow{2}{*}{ Season } & \multicolumn{3}{c}{ System } \\
\cline { 2 - 4 } & ICL & ICLF1 & ICLF2 \\
\hline Summer & $3,234 \mathrm{aA}$ & $2,142 \mathrm{bA}$ & $2,449 \mathrm{abA}$ \\
Fall & $2,821 \mathrm{aA}$ & $887 \mathrm{bB}$ & $1,555 \mathrm{bA}$ \\
Winter & $2,649 \mathrm{aA}$ & $946 \mathrm{bB}$ & $1,512 \mathrm{bA}$ \\
\hline
\end{tabular}

$\mathrm{a}>\mathrm{b}$ on the line and $\mathrm{A}>\mathrm{B}$ in the column, according to the Scott-Knott test $(\mathrm{P}<0.05)$.

Paciullo et al. (2008) found similar results for Brachiaria decumbens characteristics when they assessed the effect of three shading levels on silvopastoral systems. There was decreased forage values when the grass was subjected to higher shading rates, and it corroborated the present study, which showed that treatments involving shade (ICLF1 and ICLF2) led to lower production than systems without shade (ICL).

The highest productivity in the ICL system during the herein assessed seasons can be associated with the lower competition for light and nutrients among plants in this environment, since eucalyptus trees were not planted in it. According to Garcia and Couto (1997), the larger the number of trees in a certain site, such as in the integrated systems comprising the forest component (ICLF1 and ICLF2), the greater the competition between trees and forage for natural resources, mainly for radiation and water when these resources are limited, such as in the drought season.
There was no forage yield difference between seasons in the ICL and ICLF2 systems; however, ICLF1 presented higher yield in summer than in fall or winter. The highest grass yield in ICLF1 was recorded in summer, such result is related to better microclimatic conditions and nutrient recycling. It happens because ICLF1 contains greater tree density, fact that provides a larger amount of branches and leaves on the ground for decomposition and nutrient recycling; moreover, summer has temperatures more favorable to tropical plants such as Piatã grass.

There was higher Piatã grass leaf dry mass yield in ICL during summer, although this system did not differ from ICLF2, but was higher than ICLF1 (Table 3). The highest values recorded for ICL and the lowest for ICLF1 were observed in the fall; there were no differences in any of the systems in the winter. 
Table 3. Piatã grass leaf dry mass yield $\left(\mathrm{kg} \mathrm{ha}^{-1}\right)$, in the integrated systems: crop-livestock (ICL), crop-livestock-forest with 357 trees ha $^{-1}$ (ICLF1) and crop-livestock-forest with 227 trees ha $^{-1}$ (ICLF2), in three seasons of the year.

\begin{tabular}{cccc}
\hline \multirow{2}{*}{ Season } & & \multicolumn{2}{l}{ System } \\
\cline { 2 - 4 } & ICL & ICLF1 & ICLF2 \\
\hline Summer & $1,021 \mathrm{aA}$ & $637 \mathrm{bA}$ & $776 \mathrm{abA}$ \\
Fall & $1,084 \mathrm{aA}$ & $150 \mathrm{cB}$ & $575 \mathrm{bAB}$ \\
Winter & $462 \mathrm{aB}$ & $467 \mathrm{aAB}$ & $368 \mathrm{aB}$ \\
\hline
\end{tabular}

$\mathrm{a}>\mathrm{b}$ on the line and $\mathrm{A}>\mathrm{B}$ in the column, according to the Scott-Knott test $(\mathrm{P}<0.05)$.

Similarly, shading can impair forage leaf yield, because the lower radiation reaching the canopies does not stimulate basal and axial bud emergence for the formation of new tillers, as well does not influence leaf emergence and accumulation rates (FERNÁNDEZ et al., 2002; PACIULLO et al., 2011).

The lowest forage yield within shaded environments (Table 2) was also associated with lower leaf yield. Shaded pastures presenting lower productivity can be related to tiller death, but it is often associated with the initial plant population (FERNÁNDEZ et al., 2002).

The ICL has the highest photosynthesis rates due to the greater light incidence on the forage canopy; thus, it boosts forage tillering and higher yield; different from the ICLF1 and ICLF2 systems, which have their photosynthetic rates modified by the amount of light; therefore, the plant decreases the tillering process and prioritizes the maintenance of expended leaves.

Summer and fall were the seasons showing the highest grass leaf yield when they were compared to winter within the ICL system, it is explained by the higher rainfall rates in summer and fall than in winter. Grass leaf yield in summer did not differ from that in winter in ICLF1, but it was higher than that recorded in fall. Grass leaf yield in summer was higher than that in winter in ICLF2, but it did not differ from that recorded in fall.

Significant differences in Piatã grass leaf crude protein content (CP, \%) were recorded (Table 4). There was no difference in $\mathrm{CP}$ in systems with trees (ICLF1 and ICLF2) in summer; the lowest CP was observed in ICL. The highest content was recorded during fall in the system presenting the highest tree density, whereas the lowest content was once more recorded in systems at full sun light; moreover, the ICLF1 value in winter was higher than that of ICL, but it did not differ from ICLF2.

Table 4. Crude protein content (CP, \%) of Piatã grass leaves in the integrated systems: crop-livestock (ICL), croplivestock-forest with 357 trees $^{-1}$ (ICLF1) and crop-livestock-forest with 227 trees ha ${ }^{-1}$ (ICLF2), in three seasons of the year.

\begin{tabular}{cccc}
\hline \multirow{2}{*}{ Season } & \multicolumn{3}{c}{ System } \\
\cline { 2 - 4 } & ICL & ICLF1 & ICLF2 \\
\hline Summer & $7.25 \mathrm{bB}$ & $10.15 \mathrm{aB}$ & $10.00 \mathrm{aB}$ \\
Fall & $9.50 \mathrm{cA}$ & $14.75 \mathrm{aA}$ & $12.00 \mathrm{bA}$ \\
Winter & $10.75 \mathrm{bA}$ & $13.50 \mathrm{aA}$ & $12.25 \mathrm{abA}$ \\
\hline
\end{tabular}

$\mathrm{a}>\mathrm{b}$ on the line and $\mathrm{A}>\mathrm{B}$ in the column, according to the Scott-Knott test $(\mathrm{P}<0.05)$. 
Organic matter degradation is higher under shading due to lower soil temperature, which favors bacterial and fungal growth. These species degrade larger amounts of organic matter; thus, they boost $\mathrm{N}$ recycling in the system, fact that helps increasing $\mathrm{CP}$ and enhancing soil fertility (MACEDO et al., 2010). There is higher organic matter concentration in the soil in shaded environments than under full sun light; organic matter has nitrogen, which helps increasing the synthesis of nitrogenous compounds when it is absorbed by the roots and, consequently, increases the CP.

When the $\mathrm{CP}$ values collected during summer in the systems are compared, it is possible observing that Piatã grass from ICLF1 and ICLF2 systems present higher CP than the ICL system. Similar results were recorded by Moreira et al. (2009), who assessed the influence of Ipê Felpudo and Aroeira trees on Marandu grass in situ dry matter degradability, and found higher CP content under the shade of the trees in comparison to treatments under full sun light; results similar to those recorded in the current study were also found by Paciullo et al. (2007).

Summer was the season promoting the lowest $\mathrm{CP}$ in all integrated systems, whereas fall and winter did not differ from each other in any of the systems. The lowest Piatã grass CP recorded in summer can derive from some of the features presented by this season, such as high temperatures, high rainfall rates and long photoperiods. These features affect the growth and development of plants presenting the highest fibrous carbohydrate synthesis rates, thus they dilute the protein content inside the dry matter (TAIZ; ZEIGER, 2013).

Temperature stimulates the synthesis and decomposition of supporting tissues (leaf ribs, woody vessels) through the production of phenolic compounds such as lignin. High lignin concentrations recorded throughout summer helped forming complexes associated with plant fibrous tissues, fact that reduced the available nitrogen, as well as the available leaf and canopy CP. Wilson (1982) reviewed the effects of climatic factors in detriment to forage nutritional value and mentioned that temperature is the most important factor, because it can decrease forage digestibility at each degree centigrade increase in temperature.

The cell wall constituent (NDF, \%) was higher in the full sun system (ICL) in summer than in systems with the arboreal component, whereas in fall and winter this system did not differ from ICLF2 (Table 5). The highest NDF content in plants subjected to high luminosity conditions can be associated with the highest ratio of sclerenchyma tissues, since their cells presented thicker walls than plants growing under shading conditions (DEINUM et al., 1996). Shading diminishes plant supporting-tissues and reduces cell wall thickness.

Table 5. Neutral detergent fiber content (NDF, \%) of Piatã grass leaves in the integrated systems: crop-livestock (ICL), crop-livestock-forest with 357 trees ha-1 (ICLF1) and crop-livestock-forest with 227 trees ha $^{-1}$ (ICLF2), in three seasons of the year.

\begin{tabular}{cccc}
\hline \multirow{2}{*}{ Season } & \multicolumn{3}{c}{ System } \\
\cline { 2 - 4 } & ICL & ICLF1 & ICLF2 \\
\hline Summer & $72.50 \mathrm{aA}$ & $69.32 \mathrm{bA}$ & $70.25 \mathrm{bA}$ \\
Fall & $72.75 \mathrm{aA}$ & $69.75 \mathrm{bA}$ & $71.50 \mathrm{abA}$ \\
Winter & $68.50 \mathrm{aB}$ & $62.50 \mathrm{bB}$ & $67.00 \mathrm{aB}$ \\
\hline
\end{tabular}

$\mathrm{a}>\mathrm{b}$ on the line and $\mathrm{A}>\mathrm{B}$ in the column, according to the Scott-Knott test $(\mathrm{P}<0.05)$. 
Such reduction in NDF contents in shaded plants can be associated with lower availability of photoassimilates for secondary wall growth. Paciullo et al. (2007) found lower NDF content and increased Brachiaria decumbens in vitro dry matter digestibility (IVDMD), in shaded sites.

Summer and fall showed higher NDF in all integrated systems, as well as lower NDF in winter in all systems. The highest NDF in summer and fall in ICL can be related to higher temperatures and to higher dry matter yield (Table 2). As it was already mentioned, these seasons provide good conditions for plant growth, as well as elevated temperatures, which are ideal for tropical forage species. Elevated temperatures promote fast metabolic activity in plants, and diminish the metabolites of cell contents; therefore, photosynthesis products are rapidly converted into structural components (TAIZ; ZEIGER, 2013).
The plant provides lower amounts of photoassimilates for secondary wall formation in systems ICLF1 and ICLF2, and it may decrease cell wall constituents. Paciullo et al. (2011) studied the productive and nutritional features of Brachiaria decumbens in agro-silvopastoral systems and did not find defined alteration patterns in cell wall constituents.

According to some authors, few or no cell wall variations in shaded forages are found in the literature (PACIULLO et al., 2007; SOUSA et al., 2010).

The highest stocking rates (Animal Unit $=450$ $\mathrm{kg}$ of live weight, $\mathrm{AU} \mathrm{ha} \mathrm{h}^{-1}$ ) were observed during summer in the ICL and ICLF2 systems. The highest stocking rates in fall were observed in the ICL system, and the lowest rate was recorded in the ICLF1 system (Table 6) during winter; systems did not differ from each other.

Table 6. Stocking rate $\left(\mathrm{AU} \mathrm{ha}^{-1}\right)^{*}$ in the integrated systems: crop-livestock (ICL), crop-livestock-forest with 357 trees ha $^{-1}$ (ICLF1) and crop-livestock-forest with 227 trees ha $^{-1}$ (ICLF2), in three seasons of the year.

\begin{tabular}{cccc}
\hline \multirow{2}{*}{ Season } & \multicolumn{3}{l}{ System } \\
\cline { 2 - 4 } & ICL & ICLF1 & ICLF2 \\
\hline Summer & $3.35 \mathrm{aA}$ & $2.13 \mathrm{bA}$ & $2.96 \mathrm{aA}$ \\
Fall & $3.54 \mathrm{aA}$ & $0.39 \mathrm{cC}$ & $2.49 \mathrm{bA}$ \\
Winter & $1.37 \mathrm{aB}$ & $1.25 \mathrm{aB}$ & $1.17 \mathrm{aB}$ \\
\hline
\end{tabular}

* $\mathrm{AU}=$ animal unit, corresponding to $450 \mathrm{~kg}$ live weight. $\mathrm{a}>\mathrm{b}$ on the line and $\mathrm{A}>\mathrm{B}$ in the column, according to the Scott-Knott test $(\mathrm{P}<0.05)$.

The lowest stocking rate in fall in the ICLF1 system was influenced by the animals' removal for pasture recovery. Accordingly, it also helped the non-difference in the stocking rates recorded for these systems in winter, time when animals were once more introduced in the system. Actually, it was expected to find lower stocking rates due to the greatest tree density and the lowest grass mass yield in this system (Table 2).
The highest stocking rates in the ICL and ICLF2 systems were observed in summer and fall; as for the ICLF1 system, the highest stocking rate was recorded in summer, and the lowest in fall; it may have happened due to the animals' removal in fall. The grass may sprout and reach forage yield in winter similar to that recorded in fall and, consequently, higher animal load since the stocking rate had to be reduced due to forage yield decrease in fall (Table 2). 
There were no differences recorded for average daily gain (ADG) between integrated systems, despite the lower forage yield in systems with trees. It was found that the highest nutritional value of pasture under shading allows average daily gain similar to that recorded under full sun light conditions (PACIULLO et al., 2009). However, there was higher ADG in summer than in fall and winter, although they did not differ from each other (Table 7). This result is associated with the greater forage availability during summer to be consumed by the animals.

Table 7. Average daily gain (ADG, $g$ animal $\left.{ }^{-1} \mathrm{day}^{-1}\right)$ of Nellore heifers in three seasons of the year.

\begin{tabular}{cc}
\hline Season & ADG $\left(\mathrm{g}\right.$ animal ${ }^{-1}$ day $\left.^{-1}\right)$ \\
\hline Summer & $548 \mathrm{~A}$ \\
Fall & $364 \mathrm{~B}$ \\
Winter & $296 \mathrm{~B}$ \\
\hline
\end{tabular}

$\mathrm{A}>\mathrm{B}$ in the column, according to the Scott-Knott test $(\mathrm{p}<0.05)$.

The highest live weight values (LWG) were recorded in systems presenting higher forage yield (ICL and ICLF2) in summer and fall; whereas there were no LWG differences among the three systems in winter (Table 8). Oliveira et al. (2013) observed the same behavior in animal production, in winter LWG was similar between different production systems, even under intense shading caused by the forest component. However, LWG was reduced in summer and fall as the shade rate in the system increased. These results evidenced differences in animal performance result from higher forage mass rates, often due to greater availability of radiation for photosynthesis.

Table 8. Live weight gain (LWG, $\mathrm{kg} \mathrm{ha}^{-1}$ ) of Nellore heifers in the integrated systems: crop-livestock (ICL), croplivestock-forest with 357 trees ha $^{-1}$ (ICLF1) and crop-livestock-forest with 227 trees ha-1 $^{-1}$ (ICLF2), in three seasons of the year.

\begin{tabular}{cccc}
\hline \multirow{2}{*}{ Season } & \multicolumn{3}{c}{ Systems } \\
\cline { 2 - 4 } & ICL & ICLF1 & ICLF2 \\
\hline Summer & $263 \mathrm{aA}$ & $168 \mathrm{bA}$ & $246 \mathrm{aA}$ \\
Fall & $112 \mathrm{aB}$ & $11 \mathrm{bB}$ & $93 \mathrm{aB}$ \\
Winter & $70 \mathrm{aB}$ & $61 \mathrm{aB}$ & $31 \mathrm{aB}$ \\
\hline
\end{tabular}

$\mathrm{a}>\mathrm{b}$ on the line and $\mathrm{A}>\mathrm{B}$ in the column, according to the Scott-Knott test $(\mathrm{P}<0.05)$.

Animals presented higher LWG in summer in all systems and there was no difference between fall and winter in any of the integrated systems; thus, it evidences that the highest forage yield in summer influenced the highest LWG of heifers in this season.

It is possible stating that animal production is compromised by the large shading exerted by taller trees at the time to cut the timber, even when productive and shade-tolerant grass species are used and the proper grazing management is adopted, and when all the studied components are taken into consideration, as well as the analyses based on a systemic view.

Grass production in these systems is higher in 
summer, but it decreases in fall and winter, although at the beginning of the forage scarcity period the nutritional values increase in systems with higher tree density. These results strongly influence animal production in integrated systems with higher tree density. It is recommended to use systems with lower tree density (ICLF2) to mitigate the shading effects on annual forage yield and animal performance (5,516 kg ha-1 and $370 \mathrm{~kg} \mathrm{ha}^{-1}$ respectively) when they are compared to the well-managed integrated system under full sun light - ICL $\left(8,704 \mathrm{~kg} \mathrm{ha}^{-1}\right.$ and $445 \mathrm{~kg} \mathrm{ha}^{-1}$, respectively). Another benefit that must be taken into account in these systems is the improved soil fertility, which can be observed in the analyses conducted in the beginning of the systems' implementation and at the time the current experiment was carried out (second cycle).

\section{Conclusions}

The ICLF2 system proved to be the most suitable tree system for animal production, although shading interfered with forage yield, allowing an annual LWG of $83 \%$ in relation to the ICL system during the fifth year of establishment of the systems.

\section{Acknowledgement}

Post-Graduation Program in Animal Science (UFMS), Embrapa Gado de Corte, Valéria Ana Corvalã dos Santos and Arthur Behling Neto.

\section{References}

BALBINO, L. C.; CORDEIRO, L. A. M.; PORFÍRIODA-SILVA, V.; MORAES, A.; MARTÍNEZ, G. B.; ALVARENGA, R. C.; KICHEL, A. N.; FONTANELI, R. S.; SANTOS, H. P.; FRANCHINI, J. C.; GALERANI, P. R. Evolução tecnológica e arranjos produtivos de sistemas de integração lavoura-pecuária-floresta no Brasil. Pesquisa Agropecuária Brasileira, Brasília, v. 46, n. 10, p. 1-12, 2011.

BUNGENSTAB, D. J.; ALMEIDA, R. G. Integrated crop-livestock-forestry systems: a Brazilian experience for sustainable farming. Brasilia: EMBRAPA, 2014. 304 p.
DEINUM, B.; SULASTRI, R. D.; ZEINAB, M. H.; MAASSEN, A. Effects of light intensity on growth, anatomy and forage quality of two tropical grasses (Brachiaria brizantha and Panicum maximum var. Trichoglume). Netherlands Journal of Agricultural Science, Wageningen, v. 44, n. 2, p. 111-124, 1996.

FERNÁNDEZ, M. E.; GYENGE, J. E.; DALLA SALDA, G.; SCHLICHTER, T. M. Silvopastoral systems in northwestern Patagonia I. growth and photosynthesis of Stipa speciosa under different levels of Pinus ponderosa cover. Agroforestry Systems, Netherlands, v. 55, n. 5, p. 27-35, 2002.

FERREIRA, D. F. Sisvar: a computer statistical analysis system. Ciência e Agrotecnologia, Lavras, v. 35, n. 6, p. 1039-1042, 2011.

GARCIA,R.; COUTO,L. Silvopastoral systems: emergent technology of sustainability. In: INTERNATIONAL SYMPOSIUM ON ANIMAL PRODUCTION UNDER GRAZING, 1997, Viçosa, MG. Anais... Viçosa, MG: DZO/UFV, 1997. p. 281-302.

KIRCHNER, R.; SOARES, A. B.; SARTOR, L. R.; ADAMI, P. F.; MIGLIORINI, F.; FONSECA, L. Desempenho de forrageiras hibernais sob distintos níveis de luminosidade. Revista Brasileira de Zootecnia, Viçosa, MG, v. 39, n. 11, p. 2371-2379, 2010.

LEONEL, F. P.; PEREIRA, J. C.; COSTA, M. G.; MARCO JUNIOR, P. de; LARA, L. A.; QUEIROZ, A. C. Comportamento produtivo e características nutricionais do capim-braquiária cultivado em consórcio com milho. Revista Brasileira de Zootecnia, Viçosa, MG, v. 38, n. 1, p. 177-189, 2009.

MACEDO, R. L. G.; VALE, A. B.; VENTURIN, N. Eucalipto em sistemas agroflorestais. Lavras: UFLA, 2010.331 p.

MARTEN, G. C.; SHENK, J. S.; BARTON II, F. E. Nearinfrared reflectance spectroscopy (NIRS): analysis of forage quality. Washington: USDA, 1985. $110 \mathrm{p}$.

MARTUSCELLO, J. A.; JANK, L.; GONTIJO-NETO, M. M.; LAURA, V. A.; CUNHA, D. N. F. V. Produção de gramíneas do gênero Brachiaria sob níveis de sombreamento. Revista Brasileira de Zootecnia, Viçosa, MG, v. 38, n. 7, p. 1183-1190, 2009.

MECABÔ, C. A. Crescimento, produção e valor nutritivo do capim-Piatã em sistema agrossilvipastoril com duas densidades de eucalipto. 2014. Dissertação (Mestrado em Zootecnia) - Universidade Estadual do Oeste do Paraná, Marechal Cândido Rondon.

MOREIRA, G. R.; SALIBA, E. O. S.; MAURÍCIO, R. M.; SOUZA, L. F.; FIGUEIREDO, M. P.; GONÇALVES, L. C.; RODRIGUEZ, N. M. Avaliação da Brachiaria 
brizantha cv. marandu em sistemas silvipastoris. Arquivo Brasileiro de Medicina Veterinária e Zootecnia, Belo Horizonte, v. 61, n. 3, p. 706-713, 2009.

OLIVEIRA, C. C.; VILLELA, S. D. J.; ALMEIDA, R.G.; ALVES, F. V.; BEHLING-NETO, A.; MARTINS, P. G. M. A. Performance of Nellore heifers, forage mass, and structural and nutritional characteristics of Brachiaria brizantha grass in integrated production systems. Tropical Animal Health and Production, Edinburgh, v. 45, n. 1, p. 1-6, 2013.

PACIULLO, D. S. C.; CAMPOS, N. R.; GOMIDE, C. A. M.; CASTRO, C. R. T.; TAVELA, R. C.; ROSSIELLO, R. O. P. Crescimento de capim-braquiária influenciado pelo grau de sombreamento e pela estação do ano. Pesquisa Agropecuária Brasileira, Brasília, v. 43, n. 7, p. 917-923, 2008.

PACIUllo, D. S. C.; CARVAlho, C. A. B.; AROEIRA, L. J. M.; MORENZ, M. J. F.; LOPES, F. C.; ROSSIELLO, R. O. P. Morfofisiologia e valor nutritivo do capim-braquiária sob sombreamento natural e a sol pleno. Pesquisa Agropecuária Brasileira, Brasília, v. 42, n. 4, p. 573-579, 2007.

PACIULLO, D. S. C.; GOMIDE, C. A. M.; CASTRO, C. R. T.; FERNANDES, P. B.; MÜlleR, M. D.; PIRES, M. F. A.; FERNANDES, E. N.; XAVIER, D. F. Características produtivas e nutricionais do pasto em sistemas agrossilvipastoril, conforme distância das árvores. Pesquisa Agropecuária Brasileira, Brasília, v. 46, n. 10, p. 1176-1183, 2011.

PACIULLO, D. S. C.; LOPES, F. C. F.; MALAQUIAS JUNIOR, J. D.; VIANAFILHO, A.; RODRIGUEZ, N. M.; MORENZ, M. J. F.; AROEIRA, L. J. M. Característica do pasto e desempenho de novilhas em sistema silvipastoril e pastagem de braquiária em monocultivo. Pesquisa Agropecuária Brasileira, Brasília, v. 44, n. 11, p. 15281535, 2009.
QUINTINO, A. C.; ALMEIDA, R. G.; ABREU, J. G.; MACEDO, M. C. M.; ARANHA, A. S. Produtividade da soja em condições de sombreamento em sistemas de integração. In: CONGRESSO: SISTEMAS AGROFLORESTAIS E DESENVOLVIMENTO SUSTENTÁVEL: 10 ANOS DE PESQUISA, 2013, Campo Grande. Anais... Campo Grande: Embrapa Gado de Corte, 2013. p. 1-6.

SOUSA, L. F.; MAURÍCIO, R. M.; GONÇALVES, L. C.; SALIBA, E. O. S.; MOREIRA, G. E. Produtividade e valor nutritivo da Brachiaria brizantha cv. Marandu em um sistema Silvipastoril. Arquivo Brasileiro de Medicina Veterinária e Zootecnia, Belo Horizonte, v. 59, n. 4, p. 1029-1037, 2007.

SOUSA, L. F.; MAURÍCIO, R. M.; MOREIRA, G. R.; GONÇALVES, L. C.; BORGES, I.; PEREIRA, L. G. R. Nutritional evaluation of Braquiarão grass in association with Aroeira trees in a silvopastoral system. Agroforestry Systems, Netherlands, v. 79, n. 2, p. 189-199, 2010.

TAIZ, L.; ZEIGER, E. Fisiologia vegetal. 5. ed. Porto Alegre: Artmed, 2013. 918 p.

VALLE, C. B.; MACEDO, M. C. M.; EUCLIDES, V. P. B.; JANK, L.; RESENDE, R. M. S. Gênero Brachiaria. In: FONSECA, D. M.; MARTUSCELLO, J. A. (Ed.). Plantas forrageiras. Viçosa, MG: UFV, 2011. p. 30-77.

VARELLA, A. C.; PORFÍRIO-DA-SILVA, V.; RIBASKI, J.; SOARES, A. B.; MORAES, H.; SAIBRO, J. C.; BARRO, R. S. Estabelecimento de plantas forrageiras em sistemas de integração floresta-pecuária no Sul do Brasil. In: FONTANELI, R. S.; SANTOS, H. P.; FONTANELI, R. S. (Ed.). Forrageiras para integração lavoura-pecuária-floresta na Região Sul-Brasileira. Passo Fundo: Embrapa Trigo, 2009. p. 283-301.

WILSON, J. R. Environmental and nutritional factors affecting herbage quality. In: HACKER, J. B. (Ed.). Nutritional limits to animal production from pastures. Sta. Lucia: Commonwealth Agricultural Bureaux, 1982. p. 111-131. 
